Marquette University

e-Publications@Marquette

Chemistry Faculty Research and Publications

Chemistry, Department of

1-1-2009

\title{
A Versatile Synthesis of Electroactive Stilbenoprismands for Effective Binding of Metal Cations
}

Sergey V. Lindeman

Marquette University, sergey.lindeman@marquette.edu

Rajendra Rathore

Marquette University

Paromita Debroy

Marquette University

Accepted version. The Journal of Organic Chemistry, Vol. 74, No. 5 (2009): 2080-2087. DOI. (C) 2009

American Chemical Society. Used with permission. 
Marquette University

e-Publications@Marquette

\section{Chemistry Faculty Research and Publications/College of Arts and Sciences}

This paper is NOT THE PUBLISHED VERSION; but the author's final, peer-reviewed manuscript. The published version may be accessed by following the link in th citation below.

Journal of Organic Chemistry, Vol. 74, No. 5 (2009): 2080-2087. DOI. This article is (C) American Chemical Society and permission has been granted for this version to appear in $\underline{\text { e- }}$

Publications@Marquette. American Chemical Society does not grant permission for this article to be further copied/distributed or hosted elsewhere without the express permission from American Chemical Society.

\section{A Versatile Synthesis of Electroactive Stilbenoprismands for Effective Binding of Metal Cations}

Paromita Debray

Department of Chemistry, Marquette University, Milwaukee, WI

Sergey V. Lindeman

Department of Chemistry, Marquette University, Milwaukee, WI

Rajendra Rathore

Department of Chemistry, Marquette University, Milwaukee, WI 


\section{Abstract}

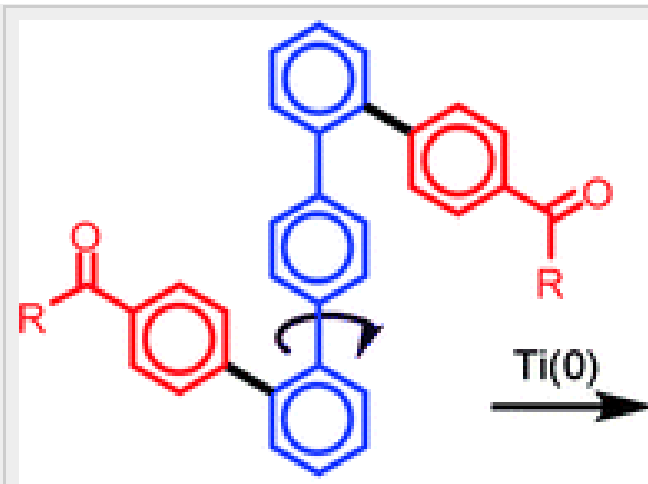

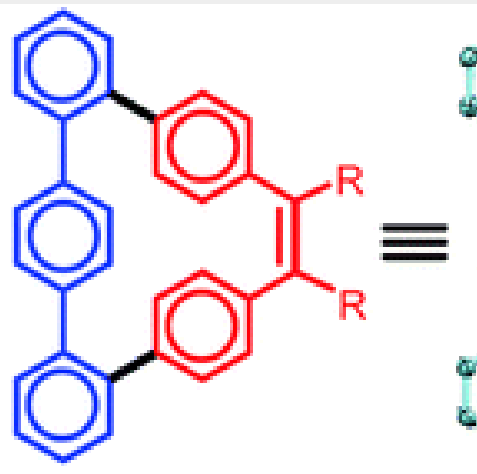

Stilbenoprismand

A versatile synthesis of a new class of polyaromatic receptors (stilbenoprismands) containing a $\Delta$-shaped cavity similar to that of the $\pi$-prismand together with an intimately coupled electroactive stilbenoid moiety was accomplished via an efficient intramolecular McMurry coupling reaction. The presence of the $\Delta$-shaped cavity in stilbenoprismands allows an efficient binding of a single silver cation as probed by ${ }^{1} \mathrm{H}$ NMR spectroscopy. Electron-rich stilbenoprismands undergo a ready oxidation to their highly robust cation-radical and dicationic salts. X-ray structure determination of a representative dicationic stilbenoprismand showed that the charges were largely localized on the tetraarylethylene moiety, which results in a twisting of the ethylenic $\mathrm{C}=\mathrm{C}$ bond by $\sim 35^{\circ}$. Moreover, the electronic coupling among the stilbenoid and $\pi$-prismand moieties in various stilbenoprismands was briefly probed by optical methods.

\section{Introduction}

Polyaromatic receptors containing multiple aromatic groups in (rigid) cofacially oriented arrays (such as cisdiarylalkenes, cyclophanes, triptycenes, deltaphanes, cylinderophanes, etc.)(1)continue to attract attention owing to their potential importance in the areas of metal-ion sensing, electrical conductors, and photoresponsive devices.(2) Among the best known metal-ion receptors, $\pi$-prismand (1) $(3)$ and a structurally analogous deltaphane 2(4) (see structures below) contain a $\Delta$-shaped cavity that is especially efficacious for binding a variety of metal cations, such as $\mathrm{Ag}^{+}, \mathrm{Tl}^{+}, \mathrm{Ga}^{+}$, etc. $(3,4)$ Unfortunately, both $\mathbf{1}$ and $\mathbf{2}$ are neither readily accessible, nor amenable to ready structural modifications for practical applications.(5) 

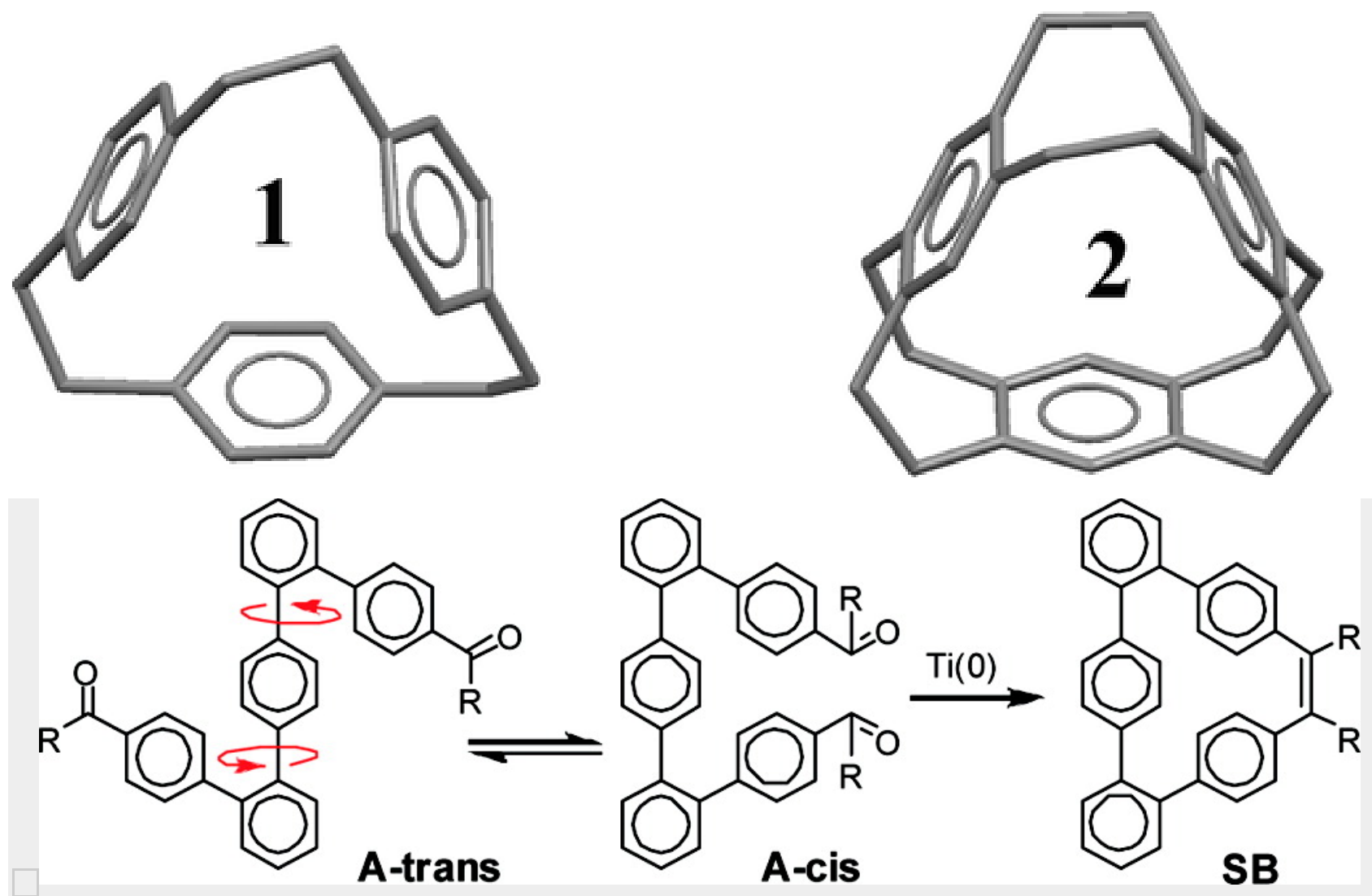

Scheme 1

It was conjectured that a polyaromatic receptor, referred to as "stilbenoprismand" (SB), containing a cavity similar to that of $\pi$-prismand 1 together with an intimately coupled electroactive stilbenoid moiety can be easily assembled via a McMurry coupling reaction of the conformationally mobile diketone A, i.e. Scheme 1.(6) The proposed route for the synthesis of SBs in Scheme 1 is based on the following observations: (i) there is ample literature precedence for the efficient preparation of large macrocycles using McMurry coupling(7) and (ii) a facile interconversion between the transcoid (A-trans) and ciscoid (A-cis) diketone conformations (Scheme 1 ), which is not readily frozen even at $-80^{\circ} \mathrm{C}$ as judged by variable-temperature ${ }^{1 H}$ NMR spectroscopy.(8)

Accordingly, herein we demonstrate that the approach in Scheme $\underline{1}$ can be successfully employed for the preparation of a number of SBs with both aliphatic and aromatic "R" groups, and their structures were established by X-ray crystallography. The SBs contain $\Delta$-shaped cavities of similar shape and size as $\mathbf{1}$ and $\mathbf{2}$ and thus bind a silver cation with efficiency similar to that of $\mathbf{1}$ or $\mathbf{2}$. Moreover, stilbenoprismands undergo reversible electrochemical oxidations and form stable cation-radicals and dicationic salts. The X-ray crystallography of a representative dicationic salt of a stilbenoprismand shows that the double bond in the stilbenoid moiety undergoes a twist of $\sim 35^{\circ}$ around the $\mathrm{C}=\mathrm{C}$ bond despite being tied into the $\pi$-prismand macrocycle. The details of these findings are described herein. 


\section{Results and Discussion}

\section{Synthesis of Stilbenoprismands (SBs)}

The essential building blocks containing a one-aryl (5) and a three-aryl unit (3) for the preparation of diketones (6) can be assembled from commercially available starting materials via Friedel-Crafts acylation and Suzuki coupling reactions, respectively (Scheme 2).
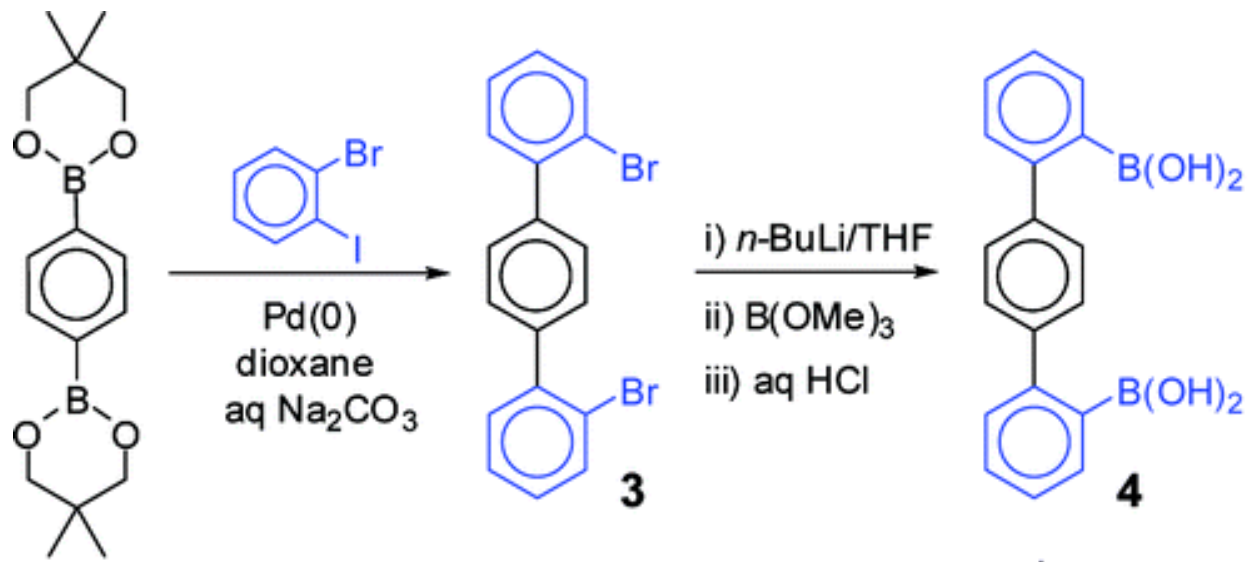

6a: $\mathrm{R}=$ methyl; $30 \%$

6b: $\mathbf{R}=n$-pentyl; $38 \%$

6c: $\mathrm{R}=$ phenyl; $82 \%$

6d: $\mathbf{R}=p$-anisyl; $78 \%$
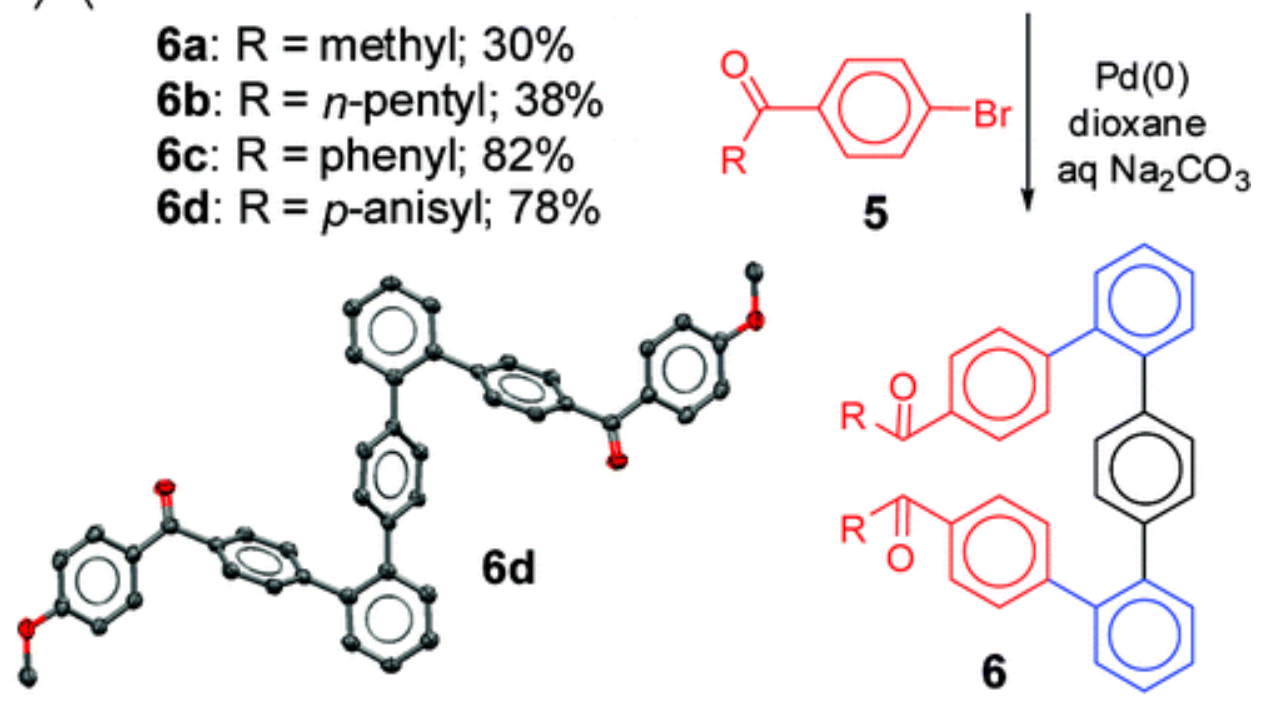

Scheme 2. A General Synthetic Scheme for the Preparation of Diketones (6a-d) and Showing a Representative X-ray Structure of $6 \mathrm{~d}$ with the Transcoid Geometry in the Solid State

For example, 2,2"-dibromo- $p$-terphenyl (3) was obtained in excellent yield ( $90 \%)$ by a Suzuki coupling reaction(9) of 1-bromo-2-iodobenzene $(10)$ with 1,4-benzenediborate ester in refluxing dioxane in the presence of aqueous sodium carbonate and a catalytic amount of $\mathrm{Pd}\left(\mathrm{PPh}_{3}\right)_{4}$. The structure of 3 was established by ${ }^{1} \mathrm{H} /{ }^{13} \mathrm{C} N M R$ spectroscopy and was further confirmed by X-ray crystallography (see the Supporting Information). A reaction of 2,2"-dibromo-pterphenyl (3) with $n$-butyllithium in tetrahydrofuran at $-78^{\circ} \mathrm{C}$ followed by treatment with trimethylborate and hydrolysis with hydrochloric acid afforded the corresponding diboronic acid $\mathbf{4}$ as a white solid in $66 \%$ isolated yield. The structure of $\mathbf{4}$ was confirmed by its conversion to the corresponding diborate ester (see the Supporting 
Information). Having 4 in hand, the syntheses of diketones 6a-d were readily accomplished via a standard Suzuki coupling reaction of $\mathbf{4}$ with various 4 -bromophenylketones, $\mathbf{5 a - d}$, to produce the corresponding diketones $\mathbf{6 a - d}$ in moderate to good yields (see Scheme 2).

To improve the yields of diketones $\mathbf{6 a}(\mathrm{R}=$ methyl) and $\mathbf{6 b}(\mathrm{R}=n$-pentyl), we sought an alternative approach. It was envisioned that $\mathbf{6 a}$ and $\mathbf{6} \mathbf{b}$ could also be accessed by the Suzuki coupling of 2,2"-dibromo-p-terphenyl (3) with the boronic acids of the corresponding bromophenylketones (e.g., 5b), i.e., Scheme $\underline{3}$.

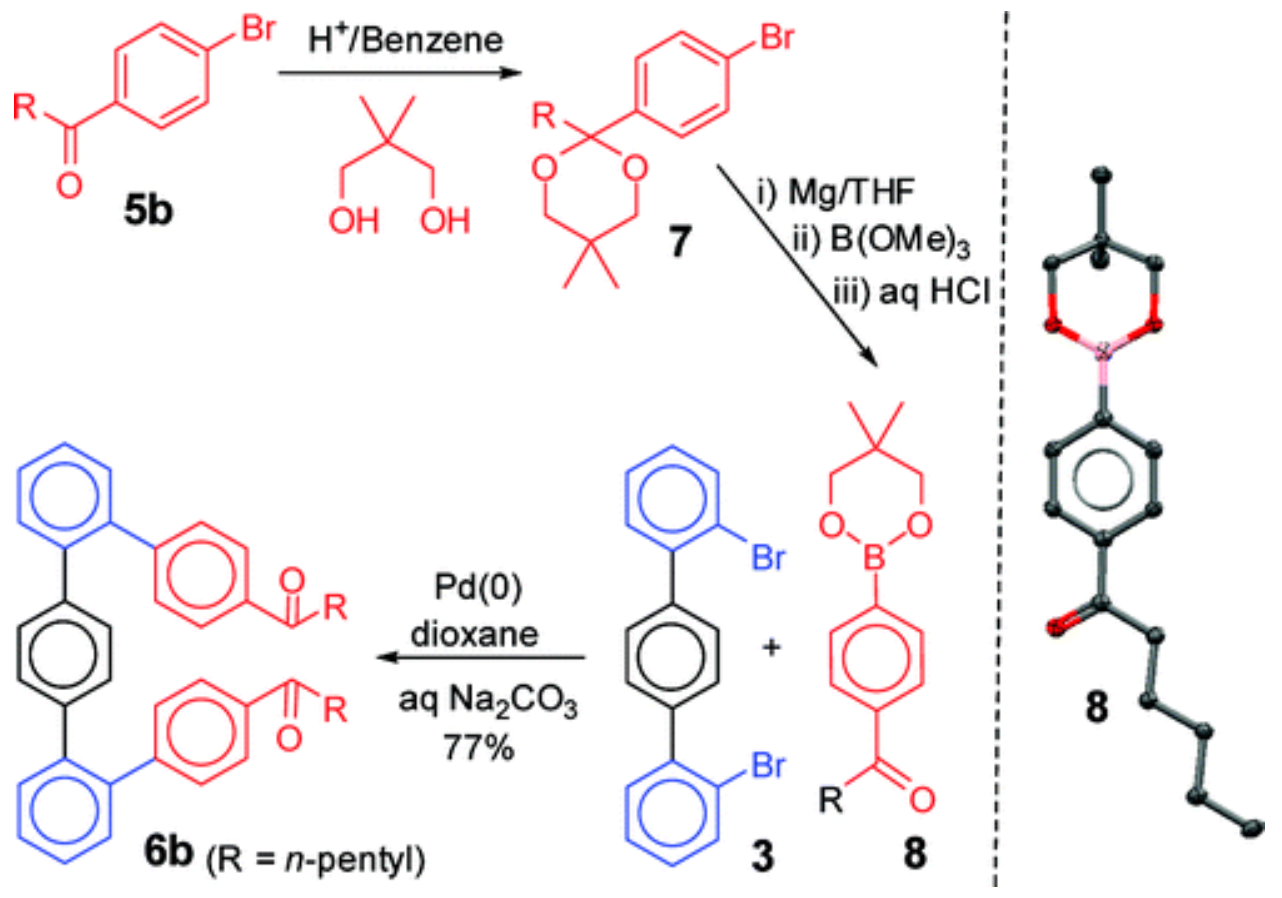

Scheme 3. An Alternative Synthetic Scheme for the Preparation of Diketone $6 \mathrm{~b}$ and X-ray Structure of an Unexpectedly Formed Borate Ester 8

Thus, a freshly prepared Grignard reagent from the protected 4-bromohexanophenone (i.e., 7) was reacted with trimethylborate in tetrahydrofuran at $-78^{\circ} \mathrm{C}$ for $12 \mathrm{~h}$, followed by quenching the resulting reaction mixture with dilute hydrochloric acid at $0{ }^{\circ} \mathrm{C}$ to afford, to our surprise, the borate ester 8 in excellent yield. The structure of the borate ester 8 was confirmed by ${ }^{1} \mathrm{H} /{ }^{13} \mathrm{C}$ NMR spectroscopy and further established by $\mathrm{X}$-ray crystallography (see Scheme $\underline{3}$ ). This observation suggests that the deprotection of the ketal and the esterification of the corresponding boronic acid occurs in a single step leading to the formation of the borate ester $\mathbf{8}$ in $84 \%$ yield. As such, this unprecedented observation may hold potential for the one-pot preparation of borate esters from protected haloarylketones and aldehydes! A Suzuki coupling reaction of the borate ester $\mathbf{8}$ with 2,2"-dibromo-p-terphenyl $\mathbf{3}$ in refluxing dioxane in the presence of aqueous sodium carbonate and a catalytic amount of $\mathrm{Pd}\left(\mathrm{PPh}_{3}\right)_{4}$ for $17 \mathrm{~h}$, indeed, afforded $\mathbf{6 b}$ in a much improved yield (77\%). 
The molecular structures of diketones $6 \mathbf{a}-\mathbf{d}$ were easily established by ${ }^{1} \mathrm{H}$ and ${ }^{13} \mathrm{C}$ NMR spectroscopy and further confirmed by mass spectrometry. Furthermore, the molecular structure of a representative diketone $6 \mathrm{~d}$, obtained by X-ray crystallography (see Scheme 2), showed that the two carbonyl groups lie on the opposite faces of the terphenyl framework in the solid state (vide supra).

An intramolecular McMurry coupling(7) of the diketones $\mathbf{6 a - d}$ under mild dilution afforded the desired SB1-4 in excellent yields (Scheme 4). For example, a solution of the diketone $\mathbf{6 a}$ in tetrahydrofuran was added slowly during a 12-h period to a refluxing slurry of $\mathrm{TiCl}_{4}$, zinc dust, and a catalytic amount of pyridine in tetrahydrofuran, and the resulting reaction mixture was refluxed for an additional $12 \mathrm{~h}$. A standard aqueous workup followed by purification of the crude reaction mixture by column chromatography afforded the SB1 in $>90 \%$ yield. The molecular structures of SB1-4 thus obtained were easily established by ${ }^{1 H} /{ }^{13} \mathrm{C}$ NMR spectroscopy and further confirmed by $\mathrm{X}$-ray crystallography (see Scheme 4 ).
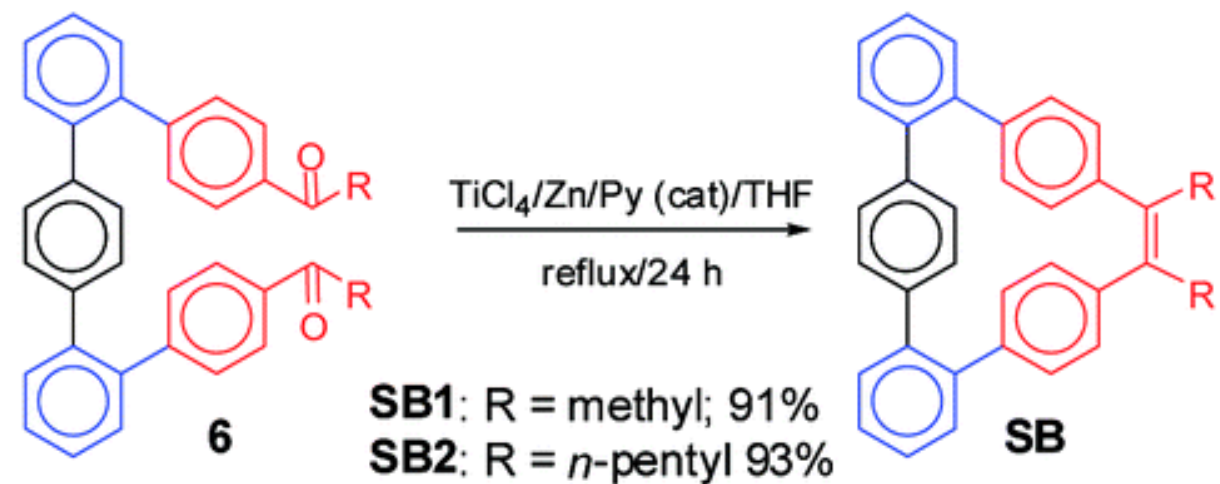

SB3: $\mathrm{R}=$ phenyl; $98 \%$

SB4: $\mathrm{R}=p$-anisyl; $96 \%$
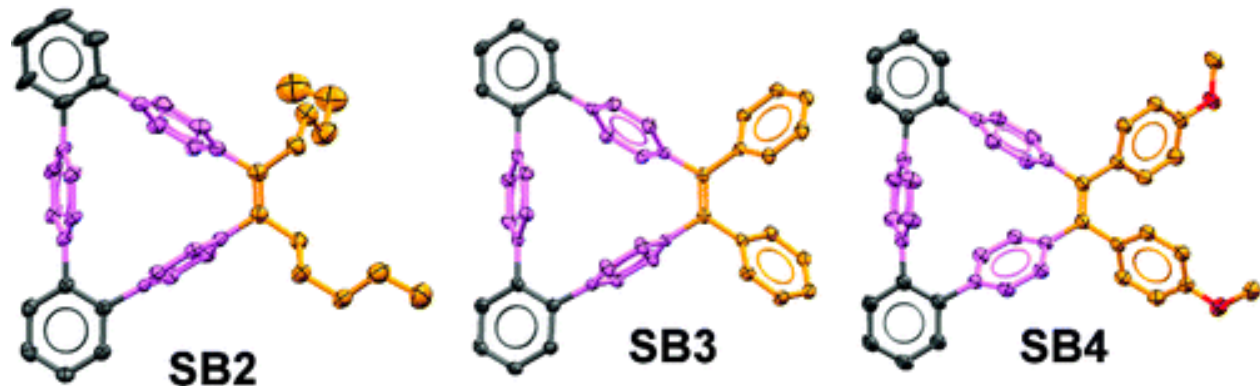

Scheme 4. A General Synthetic Scheme for the Preparation of SBs and the Molecular Structures Determined by X-ray Crystallography

The excellent yield of various stilbenoprismands in Scheme $\underline{4}$ clearly highlights the versatility of intramolecular McMurry coupling, which occurs easily via a rotation of the carbonyl bearing units about the terphenyl framework, thereby leading to the desired stilbenoprismands in excellent yields (see Scheme 1). A comparison of the geometrical parameters of SB2-4 with those for $\pi$-prismand $\mathbf{1}$ or deltaphane $\mathbf{2}$ indicated that the sizes of the $\Delta$-shaped cavity in 
various SBs were characteristically similar, i.e., an average distance from the center of the $\Delta$-shaped cavity to the center of the three benzene rings is $\sim 2.6 \AA$ in all SBs as well as in $\mathbf{1}$ and $\mathbf{2}$. This structural similarity suggested that SB1-4 should bind a silver cation with more or less similar efficiency as that of $\pi$-prismand $\mathbf{1}$ or deltaphane $\mathbf{2}$.

\section{Silver Cation Binding to Stilbenoprismands}

The binding of silver cation to readily soluble SB2 was monitored by the changes in its ${ }^{1} \mathrm{H}$ NMR spectrum in chloroform- $d$ by an incremental addition of a concentrated solution of silver trifluoromethanesulfonate in a mixture of chloroform- $d$ and methanol- $d_{4}$. The addition of the substoichiometric increments of the Ag+ solution showed considerable shifts of the aromatic signals of SB2 up to the addition of 1 equiv of $\mathrm{Ag}^{+}$, as shown in Figure $\underline{1}$. It is noteworthy that the ${ }^{1 H}$ NMR spectra remained unchanged upon further addition of $\mathrm{Ag}^{+}$solution (i.e., beyond 1 equiv). Moreover, a 1:1 complexation stoichiometry for $\left[\mathbf{S B 2}, \mathrm{Ag}^{+}\right]$was further confirmed from a plot of the changes in the chemical shift of one of the signals in ${ }^{1} \mathrm{H}$ NMR spectra against the equivalents of added Ag+ solution (Figure 1 , right). Unfortunately, an accurate binding constant for the formation of [SB2, $\left.\mathrm{Ag}^{+}\right]$could not be determined by an NMR method as it simply showed complete capture of the $\mathrm{Ag}^{+}$and suggested that the binding constant is too large to be measured by NMR spectroscopy.(11) 


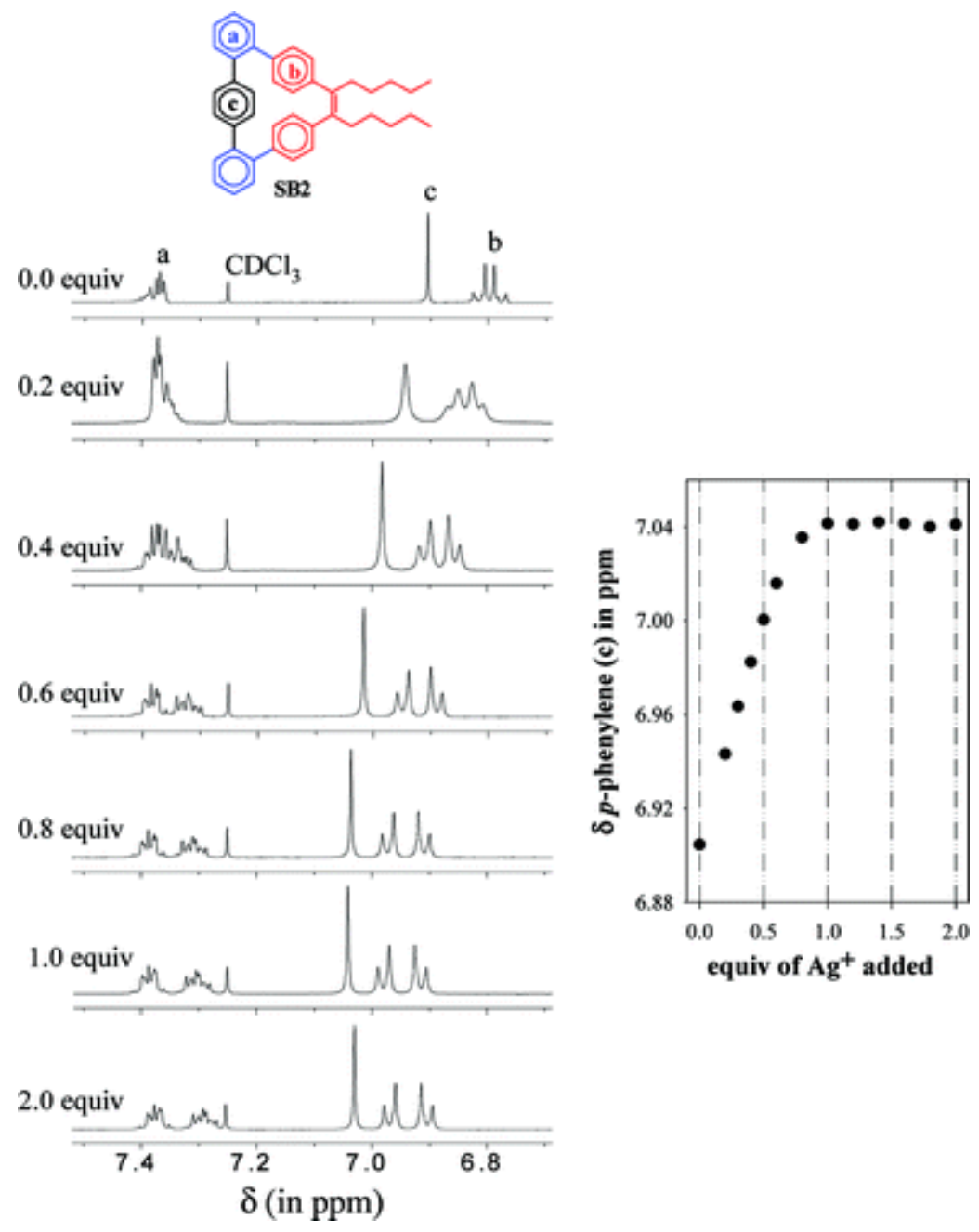

Figure 1. Left: Partial ${ }^{1 \mathrm{H}} \mathrm{NMR}$ spectra of $\mathrm{SB} 2(9 \mathrm{mM})$ in $\mathrm{CDCl}_{3}$ obtained upon an incremental addition of $\mathrm{Ag}^{+} \mathrm{CF}_{3} \mathrm{SO}_{3}-(90 \mathrm{mM})$ in $\mathrm{CDCl}_{3}-\mathrm{CD}_{3} \mathrm{OD}$ at $22^{\circ} \mathrm{C}$. Right: A plot of changes in the chemical shifts of $p$-phenylene protons (labeled " $\mathrm{c}$ ") against the added equivalents of $\mathrm{Ag}^{+} \mathrm{CF}_{3} \mathrm{SO}_{3}$.

A similar ${ }^{1} \mathrm{H}$ NMR spectral titration of the solutions of SB3 and SB4, containing two phenyl or anisyl groups, respectively, with $\mathrm{Ag}^{+}$(under identical conditions) could not be carried out as they underwent chemical oxidation to the corresponding cation radicals in the presence of $\mathrm{Ag}^{+} .(12)$

\section{Electrochemical Oxidations of SBs and Generation of Their Cation Radicals}

Ease of the oxidation of SB3 and SB4 with $\mathrm{Ag}^{+}$prompted us to evaluate their electron-donor strengths and the initial indication of their cation radical stability by cyclic voltammetry as follows.

Thus, the electron donor strengths of SBs in comparison with the model compounds [such as tetraphenylethylene (9)(13) and dianisylditolylethylene (10)(13)] were evaluated by electrochemical oxidation at a platinum electrode as 1 $\times 10^{-3} \mathrm{M}$ solutions in dichloromethane containing $0.2 \mathrm{M} \mathrm{n}-\mathrm{Bu}_{4} \mathrm{NPF}_{6}$ as the supporting electrolyte. The cyclic voltammograms of various SBs are compiled in Figure 2. It is notable that while SB2 and SB3 showed only quasireversible oxidation waves, SB4 displayed two completely reversible oxidation waves owing to the presence of 
electron-donating methoxy groups. Furthermore, the first oxidation wave of SB3 (i.e., SB3 $\rightarrow$ SB3+•) is reversible if the scanning is terminated before the start of the second oxidation event (i.e., $\mathbf{S B 3}^{+\cdot} \rightarrow \mathbf{S B 3}^{2+}$ ), see Figure 2 . A quantitative evaluation of the CV peak currents with added ferrocene (as an internal standard, $E_{\mathrm{ox}}=0.45 \mathrm{~V} \mathrm{vs} \mathrm{SCE}$ ) revealed that the oxidation potentials of SB3 ( $E_{\text {ox }}=1.27$ and $1.59 \mathrm{~V}$ vs SCE) and SB4 ( $E_{\text {ox }}=0.98$ and $1.13 \mathrm{~V}$ vs SCE) were comparable to those of the model donors tetraphenylethylene (9) and dianisylditolylethylene (10), respectively (see Table 1 ).
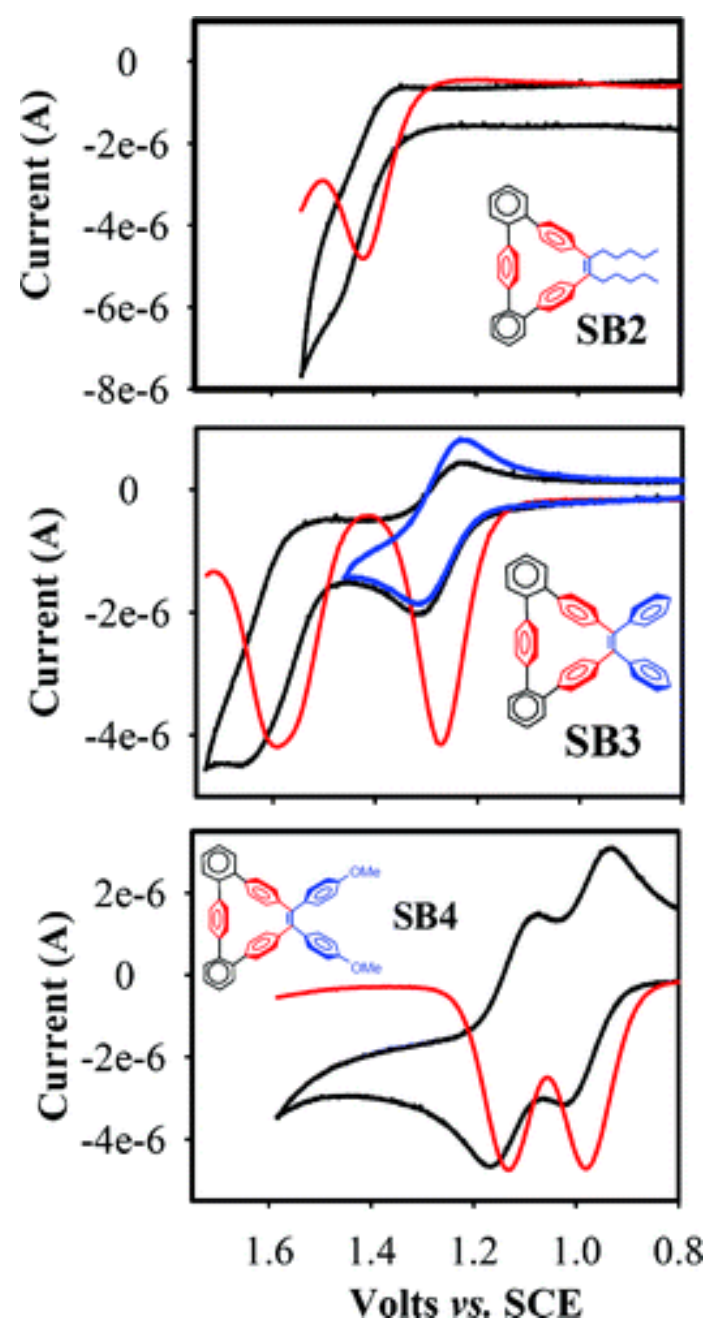

Figure 2. Cyclic voltammograms of $1 \mathrm{mM} \mathrm{SB2}, \mathbf{S B 3}$, and SB4 in dichloromethane at a scan rate of $\mathrm{v}=200 \mathrm{mV}$ $\mathrm{S}^{-1}\left(22^{\circ} \mathrm{C}\right)$. The corresponding square-wave voltammograms are shown as red curves. 
Table 1. Oxidation Potentials of Various Stilbenoprismands and the Corresponding Model Electron Donors in $\mathrm{CH}_{2} \mathrm{Cl}_{2} \mathrm{e}$

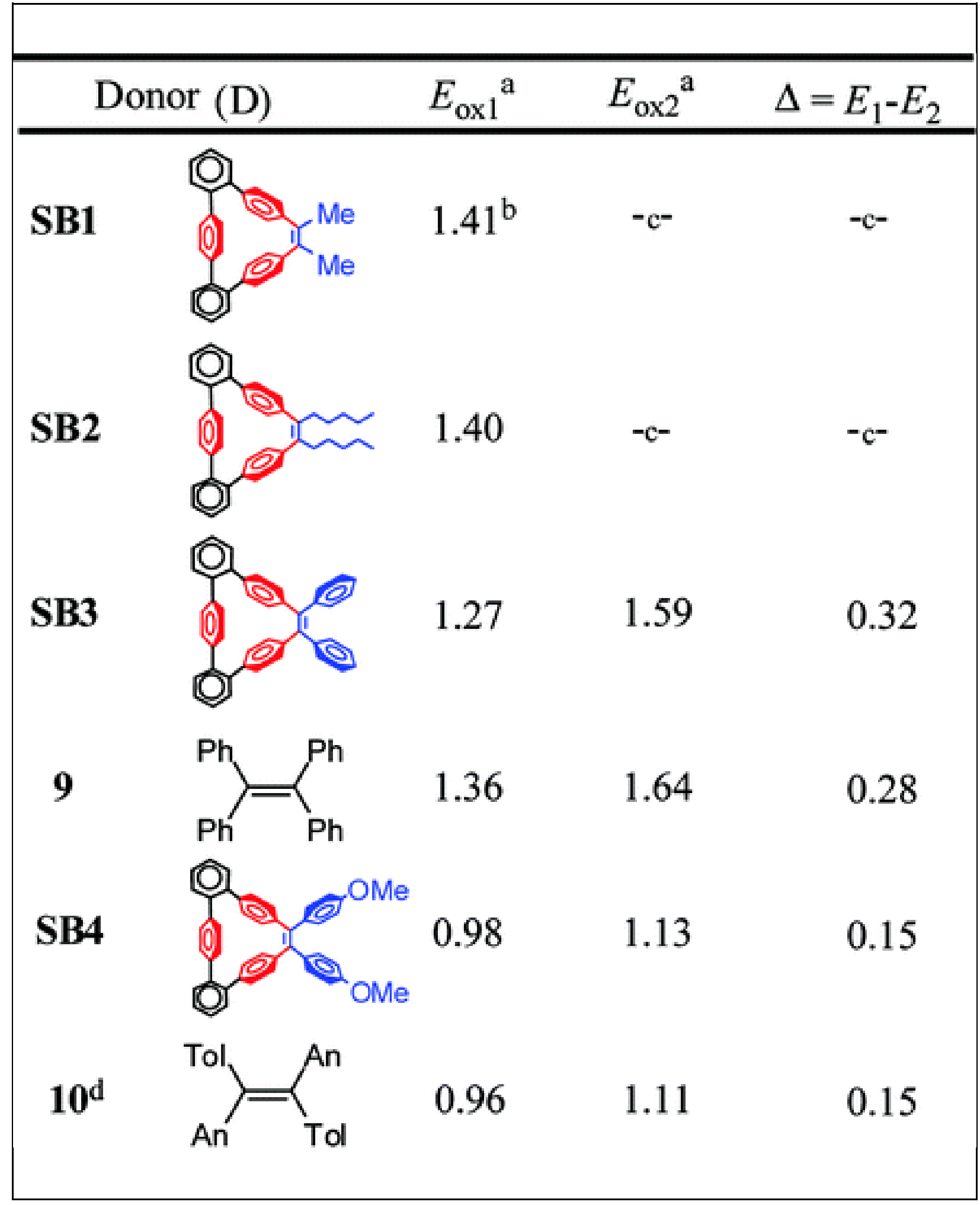

a V vs SCE at $22^{\circ} \mathrm{C}$. In dichloromethane containing $0.2 \mathrm{M}$ tetra- $n$-butylammonium hexafluorophosphate at 200 $\mathrm{mV} \mathrm{s}^{-1}$.

b Irreversible wave. 
c Second oxidation wave was not observed.

d Dianisylditolylethylene (10) consisted of a $\sim 1: 1$ cis/trans mixture.

e ph $=$ phenyl, $\mathrm{Tol}=4$-methylphenyl, $A n=4$-methoxyphenyl .

The electrochemical reversibility of SB4 and its relatively low oxidation potential prompted us to carry out its oxidation to the corresponding cation radical using a stable aromatic cation-radical salt $\mathrm{MA}^{+} \cdot \mathrm{SbCl}_{6}$ - (i.e., [1,4:5:8]dimethano-1,2,3,4,5,6,7,8-octahydro-9,10-dimethoxyanthracenium hexachloroantimonate)(14) as an oxidant $\left(E_{\text {red }}=1.11 \mathrm{~V}\right.$ vs SCE$)$. Thus, Figure $\underline{3} A$ shows the spectral changes attendant upon the reduction of $\mathbf{M A}^{*}{ }^{*}\left(\lambda_{\max }=518 \mathrm{~nm}\right.$, $\left.\log \varepsilon_{518}=3.86\right)$ by an incremental addition of substoichiometric amounts of SB4 in dichloromethane at $22{ }^{\circ} \mathrm{C}$. The presence of a well-defined isosbestic point at $\lambda_{\max }=520 \mathrm{~nm}$ (see Figure $\underline{3} \mathrm{~A}$ ) attests to an uncluttered character of the electron transfer form SB4 to $\mathbf{M A}^{*}$. Furthermore, a plot of formation of SB4+ (i.e., an increase in the absorbance at $930 \mathrm{~nm}$ ) against the increments of added SB4(Figure $\underline{3} B$ ) established that $\mathbf{M A}^{+\cdot}$ was completely consumed after the addition of 1 equiv of SB4; and the resulting absorption spectrum of the blue $\mathbf{S B 4} \mathbf{4}^{*}\left[\boldsymbol{\lambda}_{\max }=357,616\right.$, and $930 \mathrm{~nm}$; $\log$ $\left.\varepsilon_{930}=4.22\right]$ remained unchanged upon further addition of neutral SB4, i.e., eq 1.

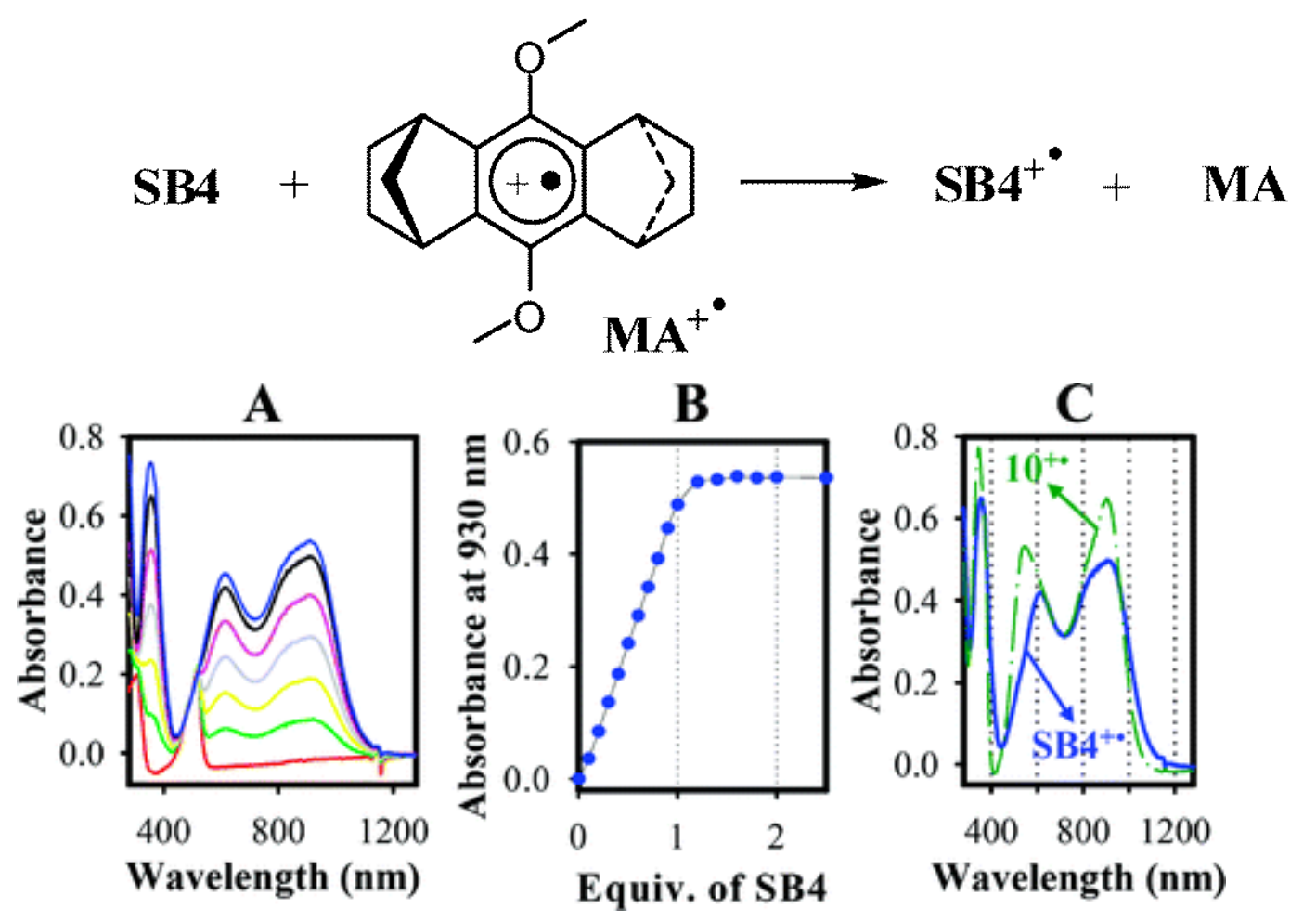

Figure 3. (A) Spectral changes upon the reduction of $3 \times 10^{-5} \mathrm{M} \mathrm{MA}^{+*}$ by an incremental addition of a $2 \times 10^{-3} \mathrm{M}$ solution of SB4 in $\mathrm{CH}_{2} \mathrm{Cl}_{2}$ at $22{ }^{\circ} \mathrm{C}$. (B) A plot of increasing absorbance of SB4+* (monitored at $930 \mathrm{~nm}$ ) against the equivalents of added SB4. Note that the depletion of absorbance of $\mathbf{M A}+\cdot$ at $\lambda_{\max }=518 \mathrm{~nm}$ could not be monitored due to the overlap of the absorption band of SB4+*. (C) A comparison of the absorption spectra of SB4+* and the model dianisylditolylethylene cation radical (10+*) under identical conditions. 
It is noteworthy that the blue SB4+*, obtained according to the eq 1 , is highly persistent at ambient temperatures and did not show any decomposition during a 12 -h period at $22^{\circ} \mathrm{C}$, as confirmed by UV-vis spectroscopy. Moreover, a reduction of SB4+• with zinc dust regenerated the neutral SB4quantitatively. It is also noted that the spectral characteristics of SB4+ closely resemble that of the cation radical of dianisylditolylethylene $\left(\mathbf{1 0}^{+*}: \lambda_{\max }=346,545\right.$, and $\left.902 \mathrm{~nm} ; \log \varepsilon_{930}=4.34\right)$, see Figure $\underline{3} \mathrm{C}$.

\section{Isolation and X-ray Crystallography of the SB4 Dication}

We have earlier shown that a stepwise one-electron oxidation of various tetraarylethylene donors (D) can be carried out by electron exchange with stable aromatic cation radicals as oxidants to selectively afford the cation radicals ( $\mathbf{D}^{+\bullet}$ ) and the dications $\left(\mathbf{D}^{2+}\right)$.(13) Furthermore, it was shown that the disproportionation of the cation radicals of the tetraarylethylenes (where aryl = phenyl, $p$-tolyl, $p$-anisyl, etc.) to the corresponding dications and neutral tetraarylethylenes (i.e., $2 \mathbf{D}^{+\bullet} \rightarrow \mathbf{D}^{2+}+\mathbf{D}$ ) are dependent on their disproportionation constants $\left(K_{\text {disp }}\right)$ which can be easily estimated from the cyclic voltammetric data (e.g., Table 1) by using the Nernstian expression $K_{\text {disp }}=\exp \left(-0.039 \Delta E^{\circ}\right)$ at $298 \mathrm{~K}$, where $\Delta E^{\circ}=E_{2}^{\circ}-E_{1}^{\circ}(\mathrm{mV}) \cdot \underline{(13)}$

It is evident from the spectral results in Figure $\underline{3}$ A/B that the SB4 cation radical is the predominant species in a dichloromethane solution and is also consistent with the low value of the estimated disproportionation constant $K_{\text {disp }}=\left[\mathrm{SB4}^{+2}\right][\mathrm{SB} 4] /\left[\mathrm{SB} 4^{+*}\right](2)=6 \times 10^{-3}$, which is comparable to the $K_{\text {disp }}$ values for the model dianisylditolylethylene donor (10).(13) Interestingly, despite the low values of disproportionation constants for various tetraarylethylene cation radicals, they all undergo crystallization-induced disproportionation to form the corresponding crystalline dicationic salts.(13) The X-ray crystallographic analysis of the dicationic salts of various tetraarylethylenes (with $\mathrm{H}, \mathrm{Me}$, and OMe substituents) as well as $\mathbf{1 0}$ showed that the central ethylenic bond undergoes a twist of $\sim 60^{\circ}$ around the central $\mathrm{C}=\mathrm{C}$ bond.(13) To experimentally determine whether SB4+2 can accommodate a similar twist around the $\mathrm{C}=\mathrm{C}$ bond, we sought to obtain its single crystals as follows.

Thus, a treatment of a solution of $\mathrm{SB} 4$ with equimolar $\mathrm{NO}+\mathrm{SbCl}_{6}-$ in anhydrous dichloromethane at $\sim 0{ }^{\circ} \mathrm{C}$ immediately resulted in a dark blue solution of SB4+* according to the stoichiometry in eq 2 .

\section{$\mathbf{S B} 4+\mathrm{NO}^{+} \mathrm{SbCl}_{6}{ }^{-} \rightarrow \mathbf{S B} 4{ }^{+\bullet} \mathrm{SbCl}_{6}{ }^{-}+\mathrm{NO}^{\uparrow}$}

The highly colored dichloromethane solution of $\mathbf{S B}^{+} \cdot \mathrm{SbCl}_{6}^{-}$salt, obtained in eq 2 , was found to be stable for days at $22{ }^{\circ} \mathrm{C}$ and was spectrally identical with that obtained above in eq 1 . The blue solution was carefully layered with toluene and stored in a refrigerator at $-10^{\circ} \mathrm{C}$ for 2 days. A good crop of dark-colored needles, thus obtained, was shown to be the dicationic [ $\mathrm{SB}_{4}^{2+}\left(\mathrm{SbCl}_{6}^{-}\right)_{2}$ ] by UV-vis spectroscopy (see Figure $\mathrm{S} 1$ in the Supporting Information) and by X-ray crystallography as follows.(15) 
Expectedly, the crystallographic analysis of the above dark-colored needles further confirmed that the crystals consisted of a dicationic salt $\left[\mathrm{SB}^{2+}\left(\mathrm{SbCl}_{6}\right)_{2}\right]$. Figure $\underline{4} \mathrm{~A}$ shows a unit cell of $\left[\mathrm{SB}^{2+}\left(\mathrm{SbCl}_{6}\right)_{2}\right]$, which is made up of columns of dicationic $\mathbf{S B} 4^{2+}$ which are surrounded by $\mathrm{SbCl}_{6}{ }^{-}$counteranions and several heavily disordered toluene and dichloromethane molecules. Despite the low experimental precision, owing to the disordered toluene molecules, the bond length changes in SB4 ${ }^{2+}$ clearly showed that the stilbenoid $C=C$ double bond [1.362(3) $\AA$ in neutral SB4] loses its bonding electrons and essentially changes into a single $C_{s p}{ }^{2} C_{s p}{ }^{2}$ bond (1.475(9) $\AA$ ). The cationic charges are largely delocalized onto the adjacent $p$-anisyl groups as judged by the shortening of the exocyclic $C-C$ bonds from 1.491(3) $\AA$ (in neutral SB4) to $1.393(9) \AA$ and of the $\mathrm{C}-\mathrm{OCH}_{3}$ bonds from 1.372(3) $\AA$ (in neutral SB4) to 1.311(9) $\AA$. Moreover, the loss of electron density from the stilbenoid ethylenic bond in $\mathbf{S B 4} 4^{+2}$ also induces a twist of $\sim 35^{\circ}$ around the $\mathrm{C}=\mathrm{C}$ bond (Figure $\underline{4}$ ) as compared to the observed twist of $\sim 60^{\circ}$ around the central $\mathrm{C}=\mathrm{C}$ bond in various tetraarylethylene dications (e.g., Figure 4 C). $(13)$ It is noteworthy that the modest twist of $\sim 35^{\circ}$ in $\mathbf{S B} 4^{+2}$ (as opposed to $\sim 60^{\circ}$ in acyclic tetraarylethylene dications) causes significant conformational deformation in the $\pi$-prismand macrocycle. For example, the $\pi$-prismand macrocycles in neutral SB2-4 are essentially planar (considering the $p$-phenylene bridges as linear) with only minor deviations (i.e., $+4.4^{\circ}$ for $\mathbf{S B 2},+5.4^{\circ}$ for $\mathbf{S B 3},+9.2^{\circ}$ for SB4) from the ideal value of the sum of the intracyclic bond angles (i.e., $\left.6 \times 120^{\circ}=720^{\circ}\right) \underline{(16)}$ due to the slight distortions $\left(\sim 3^{\circ}\right)$ in the planarity of the $p$ phenylene rings and the twist around the stilbenoid $C=C$ double bonds $\left(\sim 4^{\circ}\right)$. Interestingly, however, the oxidation of neutral SB4 to its dication (and an accompanying twist of $\sim 35^{\circ}$ around the stilbenoid $C=C$ bond) leads to a decrease in the angular deviation of $+2.9^{\circ}$ (as opposed to $+9.2^{\circ}$ in neutral SB4) from the ideal value of the sum of the intracyclic bond angles (i.e., $720^{\circ}$ ), but a significant increase in the nonplanarity of the $p$-phenylene rings in the $\pi$-prismand macrocycle (i.e., $\sim 5^{\circ}$, which is a $\sim 50 \%$ increase in the distortion of the $p$-phenylene rings as compared to the neutral SB4). 

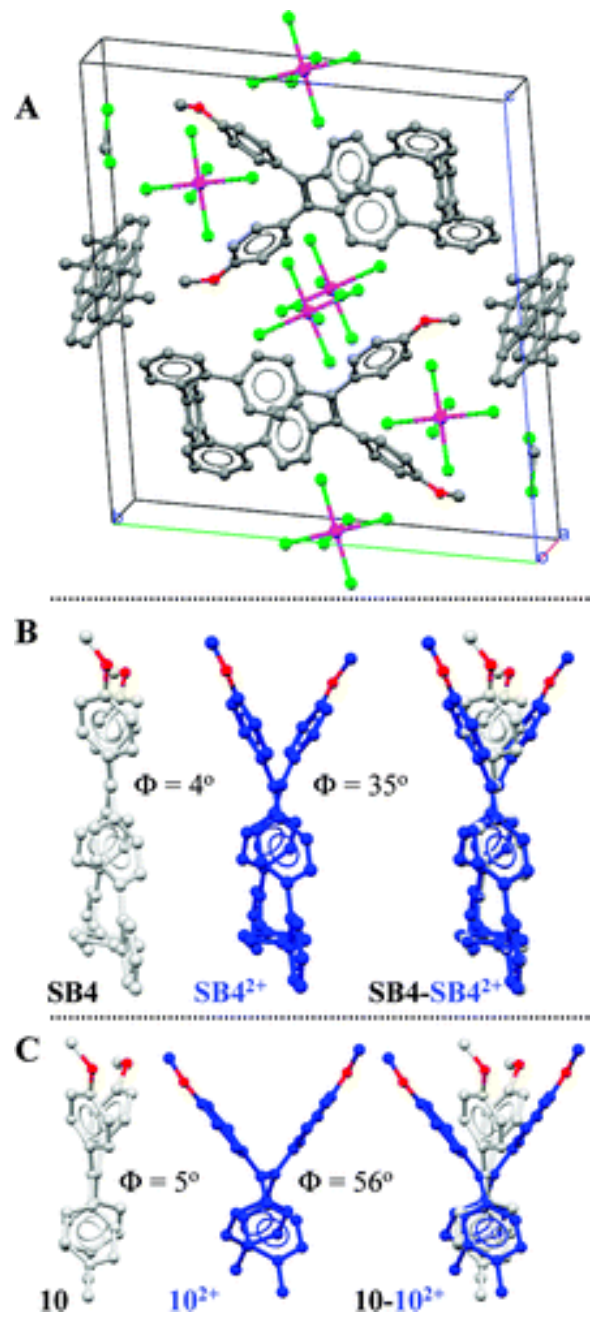

Figure 4. (A) A unit cell of the crystal structure of $\mathbf{S B 4}+2\left(\mathrm{SbCl}_{6}\right)_{2}$ showing the disordered toluene molecules. (B) The individual and superimposed structures of neutral and dicationic SB4 showing the twist around the $\mathrm{C}=\mathrm{C}$ double bond. (C) The individual and superimposed structures of neutral and dicationic $\mathbf{1 0}$ showing the twist around the $\mathrm{C}=\mathrm{C}$ double bond.

As such, the observed twist of $\sim 35^{\circ}$ in $\mathbf{S B} 4^{+2}$ does lend confidence to our earlier observations(13)that the olefinic cation radicals and dications do undergo an increasing twist around the central $\mathrm{C}=\mathrm{C}$ bond owing to the loss of its bonding electrons and these observations were not simply artifacts of the simple crystal-packing forces.

\section{Absorption and Emission Spectroscopy of the Stilbenoprismands}

Tetraarylethylenes and stilbenes are known to have exceedingly short singlet excited state lifetimes and negligible fluorescence quantum yields in solution.(17) Herein, we explore the emission/optical characteristics of various stilbenoprismands in which the stilbenoid moieties are intimately coupled with the $\pi$-prismand framework, which not only restricts the avenues available for the deactivation of the excited state but also provides a highly emissive terphenyl site for the intramolecular reorganization of the exciton energy (vide infra). 
For example, the absorption spectra of stilbenoprismands SB3 and SB4 as $2.6 \times 10^{-5}$ M solutions in dichloromethane showed similar (general) spectral band shapes and absorption maxima (see legend in Figure $\underline{5} \mathrm{~A}$ ) as the model tetraphenylethylene (9) and dianisylditolylethylene (10) with poorly resolved vibrational structures (Figure $\underline{5} \mathrm{~A})$. As expected, SB2 with the alkyl substituents (rather than phenyls) displayed a relatively blue-shifted absorption envelope similar to the one observed for the stilbenes.(18)
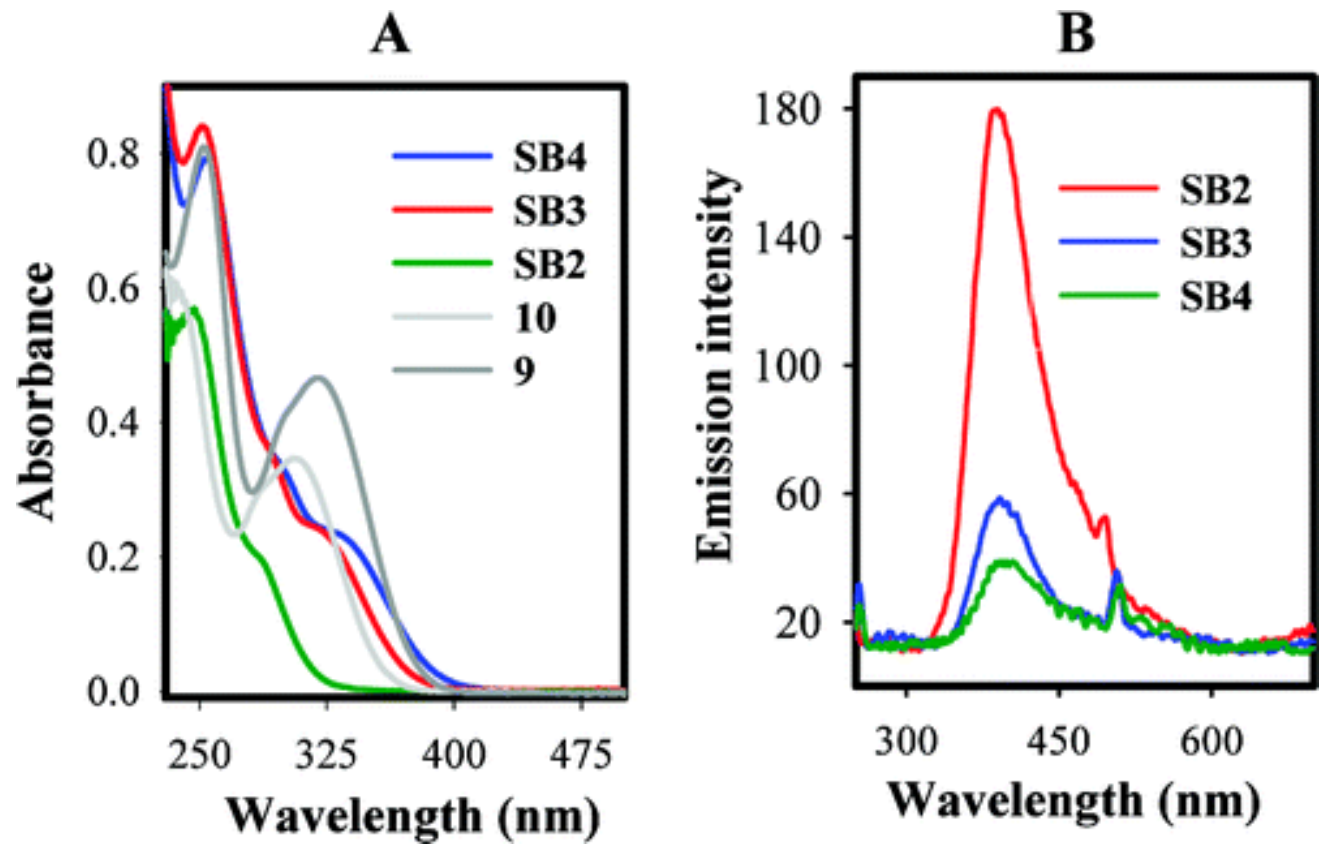

Figure 5. (A) A comparison of the UV-vis spectral profile of SB2 $\left(\lambda_{\max }=247 \mathrm{~nm}, \log \varepsilon_{247}=4.33\right), \mathbf{S B 3}\left(\lambda_{\max }=252 \mathrm{~nm}\right.$, $\left.\log \varepsilon_{252}=4.50\right)$, SB4 $\left(\lambda_{\text {max }}=253 \mathrm{~nm}, \log \varepsilon_{253}=4.47\right), 9\left(\lambda_{\max }=236\right.$ and $\left.305 \mathrm{~nm}, \log \varepsilon_{236}=4.31\right)$, and $10\left(\lambda_{\text {max }}=252\right.$ and $319 \mathrm{~nm}$, $\left.\log \varepsilon_{252}=4.50\right)$ as $2.6 \times 10^{-5} \mathrm{M}$ solutions in $\mathrm{CH}_{2} \mathrm{Cl}_{2}$. (B) Emission spectra of SB2 $\left(\lambda_{\max }=392 \mathrm{~nm}\right)$, SB3 $\left(\lambda_{\max }=\right.$ $392)$, and SB4 $\left(\lambda_{\max }=398\right)$ as $2.6 \times 10^{-5} \mathrm{M}$ solutions in $\mathrm{CH}_{2} \mathrm{Cl}_{2}$ (excitation wavelength $250 \mathrm{~nm}$ ).

The emission spectra of the parent tetraphenylethylene (9) or the dianisylditolylethylene (10) showed no detectable emission;(17) however, the SB2-4, under similar conditions, showed significant emission (Figure $\underline{5}$ B). As such, the observation of emission from stilbenoprismands would suggest that the emission must be arising from a reorganization of the exciton energy from the stilbenoid moiety to the terphenyl group of the $\pi$-prismand framework.(19) Indeed, a comparison of the emission spectrum of terphenyl (TP)(20) with that of SBs showed a reasonable spectral similarity. Further studies using time-resolved spectroscopy as well as theoretical calculations will be required to pinpoint the origin of the observed emission in various stilbenoprismands.(21)

In summary, we have successfully demonstrated a versatile synthesis of $\pi$-prismand based receptors that can be readily tailored by varying the " $R$ " groups for the desired applications. The presence of the $\Delta$-shaped cavity in SBs allows an efficient binding of silver cation, which can be monitored with the aid of ${ }^{1} \mathrm{H}$ NMR spectroscopy.

Furthermore, highly electroactive SB3 and SB4undergo ready oxidation to their highly robust and stable cation-radical salts. The isolation and X-ray crystallography of the dicationic salt of SB4 allows us to demonstrate that the charge is 
largely localized on the tetraarylethylene moiety, which undergoes a somewhat limited twist $\left(\sim 35^{\circ}\right)$ around the $\mathrm{C}=\mathrm{C}$ bond as compared to the twist of $\sim 60^{\circ}$ around the $\mathrm{C}=\mathrm{C}$ bond in various dicationic tetraarylethylenes.

\section{Experimental Section}

Nitrosonium hexachloroantimonate was prepared from a reaction of $\mathrm{SbCl}_{5}$ and $\mathrm{NOCl}$ in dichloromethane at $-78^{\circ} \mathrm{C}$ and the resulting salt was recrystallized from a dichloromethane-hexanes mixture and stored in an inert-atmosphere glovebox.(22) (See the Supporting Information for a General Experimental Section.)

\section{Preparation of 2,2"-Dibromo-p-terphenyl (3)}

A mixture of 1-bromo-2-iodobenzene $(3.10 \mathrm{~g}, 24 \mathrm{mmol})$ and 1,4-benzenediborate ester $(3.62 \mathrm{~g}, 12 \mathrm{mmol})$ in dioxane $(60 \mathrm{~mL})$ in the presence of degassed $2 \mathrm{M}$ aqueous sodium carbonate $(30 \mathrm{~mL})$ and a catalytic amount of $\operatorname{Pd}\left(\mathrm{PPh}_{3}\right)_{4}(0.27$ $\mathrm{g}, 0.24 \mathrm{mmol}$ ) was refluxed for $12 \mathrm{~h}$ under an argon atmosphere. A standard aqueous workup and crystallization of the resulting solid from a mixture of dichloromethane/hexanes afforded 3 as a crystalline white solid (4.1 g, $87 \%$ ): $\mathrm{mp}$

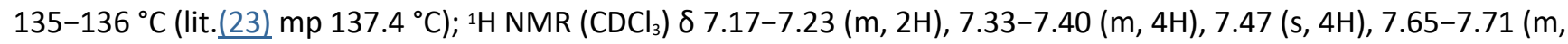
$2 \mathrm{H}) ;{ }^{13} \mathrm{C} \mathrm{NMR}\left(\mathrm{CDCl}_{3}\right) \delta 122.8,127.7,129.1,129.3,131.7,133.5,140.5,142.4$.

\section{Preparation of 2,2"-p-Terphenyldiboronic Acid (4)}

A Schlenk flask containing a solution of 2,2"-dibromo-p-terphenyl (3; $4.03 \mathrm{~g}, 10.4 \mathrm{mmol}$ ) in anhydrous THF (30 mL) was cooled to $-78^{\circ} \mathrm{C}$ under an argon atmosphere. To this solution was added $n$-BuLi $(10.4 \mathrm{~mL}, 26 \mathrm{mmol}, 2.5 \mathrm{M}$ in hexanes) dropwise, and the resulting mixture was stirred for $2 \mathrm{~h}$ at $-78^{\circ} \mathrm{C}$. Trimethylborate $(5.2 \mathrm{~mL}, 45.7 \mathrm{mmol})$ was added dropwise (with the aid of a syringe) to the above mixture and the resulting mixture was allowed to warm to room temperature during a 12-h period with stirring. The reaction was quenched by addition of $2 \mathrm{~N} \mathrm{HCl}(40 \mathrm{~mL})$ and the resulting mixture was stirred for an additional $3 \mathrm{~h}$ and extracted with ether $(3 \times 50 \mathrm{~mL})$. The ether layer was washed with water $(3 \times 50 \mathrm{~mL})$ and brine $(50 \mathrm{~mL})$ and dried over anhydrous $\mathrm{MgSO}_{4}$. Concentration in vacuo and subsequent trituration with hexane resulted in a white solid diboronic acid 4, which was separated by filtration $(2.2 \mathrm{~g}$, $66 \%)$. The 4 was characterized by its conversion to the corresponding diborate ester as follows.

Diboronic acid 4 ( $2.00 \mathrm{~g}, 6.3 \mathrm{mmol})$ was converted to the corresponding diborate ester by a reaction with pinacol $(2.23 \mathrm{~g}, 18.9 \mathrm{mmol})$ and a catalytic amount of $p$-toluenesulfonic acid $(0.10 \mathrm{~g})$ in refluxing benzene with use of a Dean-Stark apparatus. After cooling, the benzene was removed under reduced pressure and the resulting solid was dissolved in dichloromethane $(100 \mathrm{~mL})$ and washed with aqueous $\mathrm{NaHCO}_{3}(2 \times 25 \mathrm{~mL})$ and brine $(1 \times 25 \mathrm{~mL})$ and dried over $\mathrm{MgSO}_{4}$. Evaporation of the solvent and crystallization of the resulting solid from a mixture of dichloromethane/hexanes afforded the diborate ester of 4 as a white solid. Yield $1.82 \mathrm{~g}, 60 \% ; \mathrm{mp} 219-220{ }^{\circ} \mathrm{C} ;{ }^{1} \mathrm{H}$ NMR $\left(\mathrm{CDCl}_{3}\right) \delta 1.22(\mathrm{~s}, 24 \mathrm{H}), 7.31-7.49(\mathrm{~m}, 10 \mathrm{H}), 7.71-7.73(\mathrm{~m}, 2 \mathrm{H}) ;{ }^{13} \mathrm{C} \mathrm{NMR}\left(\mathrm{CDCl}_{3}\right)$ \& 24.8, 83.9, 126.4, 128.8, 129.2, 130.2, $134.6,142.0,147.5$. 


\section{Preparation of Diketones 6a-d: Typical Procedure}

A solution of 2,2"-p-terphenyldiboronic acid $(4 ; 1.27 \mathrm{~g}, 4 \mathrm{mmol})$ in dioxane $(30 \mathrm{~mL})$ in the presence of degassed $2 \mathrm{M}$ aqueous sodium carbonate $(15 \mathrm{~mL})$, 4-bromobenzophenone $(2.61 \mathrm{~g}, 10 \mathrm{mmol})$, and $\mathrm{Pd}\left(\mathrm{PPh}_{3}\right)_{4}(0.09 \mathrm{~g}, 0.08 \mathrm{mmol})$ was refluxed for $48 \mathrm{~h}$. After cooling, the reaction mixture was quenched with $5 \%$ hydrochloric acid $(30 \mathrm{~mL})$. A standard aqueous workup afforded a solid that was purified by crystallization from a mixture of dichloromethane/acetonitrile to furnish $6 \mathrm{c}$ as a white solid. Yield $1.94 \mathrm{~g}, 82 \% ; \mathrm{mp} 217-218{ }^{\circ} \mathrm{C} ;{ }^{1} \mathrm{H}$ NMR $\left(\mathrm{CDCl}_{3}\right) \delta 7.02(\mathrm{~s}, 4 \mathrm{H}), 7.23(\mathrm{~s}, 2 \mathrm{H}), 7.40-7.57$ (m, 16H), 7.65 (d, $J=8 \mathrm{~Hz}, 4 \mathrm{H}), 7.74(\mathrm{~d}, J=8 \mathrm{~Hz}, 4 \mathrm{H}) ;{ }^{13} \mathrm{C} \mathrm{NMR}\left(\mathrm{CDCl}_{3}\right) \delta 127.8,128.4,129.8,129.9,130.1,130.6,130.9$, $132.4,135.6,137.8,139.5,139.6,140.3,146.1,196.5$.

Following a similar procedure as above, reactions of 2,2"-p-terphenyldiboronic acid (4; $1.27 \mathrm{~g}, 4 \mathrm{mmol})$ with 4bromoacetophenone $(2.0 \mathrm{~g}, 10 \mathrm{mmol})$ or 4-bromohexanophenone $\underline{6})(2.61 \mathrm{~g}, 10 \mathrm{mmol})$ or 4-bromo-4'methoxybenzophenone $(2.91 \mathrm{~g}, 10 \mathrm{mmol}$ ) afforded the corresponding diketones $\mathbf{6 a}, \mathbf{6 b}$, and $\mathbf{6 d}$, respectively, and their yields and spectral data are summarized below:

6a: yield $0.60 \mathrm{~g}, 30 \%$ (after column chromatography with 8:2 hexanes-ethyl acetate as eluent); $\mathrm{mp} 210-211^{\circ} \mathrm{C} ;{ }^{1} \mathrm{H}$ $\operatorname{NMR}\left(\mathrm{CDCl}_{3}\right) \delta 2.62(\mathrm{~s}, 6 \mathrm{H}), 7.01(\mathrm{~s}, 4 \mathrm{H}), 7.25(\mathrm{~d}, J=8 \mathrm{~Hz}, 4 \mathrm{H}), 7.43-7.46(\mathrm{~m}, 8 \mathrm{H}), 7.84(\mathrm{~d}, J=8 \mathrm{~Hz}, 4 \mathrm{H}) ;{ }^{13} \mathrm{C} \mathrm{NMR}_{\left(\mathrm{CDCl}_{3}\right)}$ $\delta 26.8,127.8,128.1,128.4,129.7,130.2,130.6,130.9,135.4,139.4,139.6,140.2,146.7$, 198.1. 6 b: yield $1.11 \mathrm{~g}, 48 \%$ (after column chromatography with 9:1 hexanes-ethyl acetate as eluent); mp 166-167 ${ }^{\circ} \mathrm{C} ;{ }^{1} \mathrm{H} \mathrm{NMR}\left(\mathrm{CDCl}_{3}\right) \delta 0.89$ (t, $J=7 \mathrm{~Hz}, 6 \mathrm{H}), 1.33-1.36(\mathrm{~m}, 8 \mathrm{H}), 1.70-1.75(\mathrm{~m}, 4 \mathrm{H}), 2.94(\mathrm{t}, J=7 \mathrm{~Hz}, 4 \mathrm{H}), 6.97(\mathrm{~s}, 4 \mathrm{H}), 7.21(\mathrm{~d}, J=8 \mathrm{~Hz}, 4 \mathrm{H})$, 7.40-7.43 (m, 8H), $7.81(\mathrm{~d}, J=8 \mathrm{~Hz}, 4 \mathrm{H}) ;{ }^{13} \mathrm{C} \mathrm{NMR}\left(\mathrm{CDCl}_{3}\right) \delta$ 14.2, 22.8, 24.3, 31.8, 38.8, 127.9, 128.3, 129.7, 130.2, $130.6,130.9,135.4,139.5,139.6,140.3,146.4,200.5$. $6 \mathrm{~d}$ : yield $1.64 \mathrm{~g}, 63 \%$ (after recrystallization from a mixture of dichloromethane/acetonitrile); $\mathrm{mp} 151-152{ }^{\circ} \mathrm{C} ;{ }^{1} \mathrm{H} \mathrm{NMR}\left(\mathrm{CDCl}_{3}\right) \delta 3.85(\mathrm{~s}, 6 \mathrm{H}), 6.91(\mathrm{~d}, J=9 \mathrm{~Hz}, 4 \mathrm{H}), 7.02(\mathrm{~s}, 4 \mathrm{H}), 7.24$ $(\mathrm{d}, J=8 \mathrm{~Hz}, 4 \mathrm{H}), 7.45(\mathrm{~s}, 8 \mathrm{H}), 7.62(\mathrm{~d}, J=8 \mathrm{~Hz}, 4 \mathrm{H}), 7.76(\mathrm{~d}, J=9 \mathrm{~Hz}, 4 \mathrm{H}) ;{ }^{13} \mathrm{C} \mathrm{NMR}\left(\mathrm{CDCl}_{3}\right) \delta 55.6,113.6,127.8,128.3$, 129.6, 129.7, 129.8, 130.3, 130.6, 130.8, 132.6, 136.3, 139.65, 139.68, 140.3, 145.6, 163.2, 195.3.

\section{Alternate Preparation of the Diketone $6 \mathrm{~b}$ with the Route in Scheme $\underline{3}$}

Preparation of acetal 7: Reaction of 4-bromohexanophenone(6) (5b; $6.4 \mathrm{~g}, 25 \mathrm{mmol}$ ) with 2,2-dimethyl-1,3propanediol $(7.82 \mathrm{~g}, 75 \mathrm{mmol})$ in the presence of a catalytic amount of $p$-toluenesulfonic acid $(0.2 \mathrm{~g})$ in toluene (130 $\mathrm{mL}$ ) under standard conditions afforded pure acetal $7(7.31 \mathrm{~g}, 86 \%)$ as a viscous liquid, after column chromatography with 9:1 hexanes-ethyl acetate as eluent. ${ }^{1} \mathrm{H} \mathrm{NMR}\left(\mathrm{CDCl}_{3}\right) \delta 0.47(\mathrm{~s}, 3 \mathrm{H}), 0.73(\mathrm{t}, J=7 \mathrm{~Hz}, 3 \mathrm{H}), 1.07-1.26(\mathrm{~m}, 9 \mathrm{H})$, 1.57-1.63 (m, 2H), $3.27(\mathrm{~s}, 4 \mathrm{H}), 7.17(\mathrm{~d}, J=8 \mathrm{~Hz}, 2 \mathrm{H}), 7.40(\mathrm{~d}, J=8 \mathrm{~Hz}, 2 \mathrm{H}) ;{ }^{13} \mathrm{C} \mathrm{NMR}\left(\mathrm{CDCl}_{3}\right) \delta$ 14.3, 22.0, 22.8, 23.1, $30.2,32.1,44.7,71.7,101.5,121.8,129.4,131.7,139.4$. Preparation of borate ester 8: A freshly prepared solution of Grignard reagent [from 7 (4.44 g, $13 \mathrm{mmol})$ and excess $\mathrm{Mg}$ turnings $(0.94 \mathrm{~g}, 39 \mathrm{mmol})$ in anhydrous THF (30 mL)] was transferred with the aid of cannula to a Schlenk flask containing a solution of trimethylborate $(2.0 \mathrm{~mL}, 17 \mathrm{mmol})$ in 
anhydrous THF $(25 \mathrm{~mL})$ at $-78{ }^{\circ} \mathrm{C}$. The resulting mixture was allowed to warm to room temperature during a $12 \mathrm{~h}$ period and was then treated with $6 \mathrm{~N} \mathrm{HCl}(15 \mathrm{~mL})$ and stirred for an additional $4 \mathrm{~h}$. The organic layer was separated and the aqueous layer was extracted with diethyl ether $(3 \times 50 \mathrm{~mL})$. The combined organic extracts were dried over anhydrous $\mathrm{MgSO}_{4}$, filtered, and evaporated. Purification of the crude solid by column chromatography on silica gel with hexane-ethyl acetate as eluent afforded the pure borate ester 8 as a white solid $(3.3 \mathrm{~g}, 84 \%): \mathrm{mp} 52-53^{\circ} \mathrm{C} ;{ }^{1} \mathrm{H}$ $\operatorname{NMR}\left(\mathrm{CDCl}_{3}\right) \delta 0.90(\mathrm{t}, J=7 \mathrm{~Hz}, 3 \mathrm{H}), 1.02(\mathrm{~s}, 6 \mathrm{H}), 1.36(\mathrm{~s}, 4 \mathrm{H}), 1.73(\mathrm{t}, J=7 \mathrm{~Hz}, 2 \mathrm{H}), 2.96(\mathrm{t}, J=7 \mathrm{~Hz}, 2 \mathrm{H}), 3.78(\mathrm{~s}, 4 \mathrm{H})$, $7.86(\mathrm{~d}, J=8 \mathrm{~Hz}, 2 \mathrm{H}), 7.91$ (d, $J=8 \mathrm{~Hz}, 2 \mathrm{H}) ;{ }^{13} \mathrm{C} \mathrm{NMR}\left(\mathrm{CDCl}_{3}\right) \delta$ 12.7, 20.6, 21.3, 22.8, 30.3, 30.6, 37.5, 71.1, 125.7, 132.7, 137.3, 199.8. Preparation of diketone $6 \mathrm{~b}$ : To a Schlenk flask was added borate ester 8 ( $3.0 \mathrm{~g}, 9.8 \mathrm{mmol}$ ) and dioxane $(60 \mathrm{~mL})$ under an argon atmosphere and the flask was subjected to three cycles of alternate evacuation and purging with argon. Degassed $2 \mathrm{M}$ aqueous sodium carbonate $(20 \mathrm{~mL}), 2,2^{\prime \prime}$-dibromo-p-terphenyl (3; $1.75 \mathrm{~g}, 4.5$ $\mathrm{mmol})$ and $\mathrm{Pd}\left(\mathrm{PPh}_{3}\right)_{4}(0.15 \mathrm{~g}, 0.13 \mathrm{mmol})$ were then added successively under an argon atmosphere. The resulting mixture was refluxed for $17 \mathrm{~h}$, cooled to room temperature, and quenched with $5 \%$ aqueous hydrochloric acid (50 $\mathrm{mL})$. The organic layer was separated and the aqueous layer was extracted with dichloromethane $(3 \times 50 \mathrm{~mL})$. The combined organic extracts were dried over anhydrous magnesium sulfate and filtered. Evaporation of the solvent afforded crude $\mathbf{6 b}$, which was purified by crystallization from a mixture of chloroform/methanol to give $\mathbf{6 b}$ as a white crystalline solid $(1.85 \mathrm{~g}, 71 \%)$, which was identical with the sample of $6 \mathbf{b}$ obtained above according to the Scheme 1 .

\section{Preparation of Stilbenoprismands SB1-4: Typical Procedure}

To a chilled $\left(\sim 0^{\circ} \mathrm{C}\right)$ Schlenk flask containing anhydrous tetrahydrofuran $(150 \mathrm{~mL})$ was added $\mathrm{TiCl}_{4}(1.2 \mathrm{~mL}, \sim 11 \mathrm{mmol})$ dropwise with the aid of a dropping funnel under an argon atmosphere. To this mixture was then added $\mathrm{Zn}$ dust (1.0 $\mathrm{g}, 15.3 \mathrm{mmol})$ and dry pyridine $(0.05 \mathrm{~mL}, 0.6 \mathrm{mmol})$ and a black suspension thus obtained was warmed to room temperature and refluxed for an additional $2 \mathrm{~h}$. A solution of the diketone $6 \mathrm{~b}(1.04 \mathrm{~g}, 1.80 \mathrm{mmol})$ in THF $(80 \mathrm{~mL})$ was added dropwise to the above mixture during a course of $20 \mathrm{~h}$ while refluxing, and the resulting mixture was refluxed for an additional $12 \mathrm{~h}$. The reaction mixture was cooled to room temperature and quenched with $10 \%$ aqueous $\mathrm{K}_{2} \mathrm{CO}_{3}(50 \mathrm{~mL})$. The organic layer was separated, and the aqueous suspension was extracted with dichloromethane (5 $\times 25 \mathrm{~mL}$ ). The combined organic extracts were dried over anhydrous $\mathrm{MgSO}_{4}$, filtered, and evaporated to afford a syrupy liquid that was purified by flash chromatography on silica gel by using a 1:9 mixture of ethyl acetate/hexanes to afford pure SB2 $(0.91 \mathrm{~g}, 93 \%)$ as a white crystalline solid. Mp $142-143{ }^{\circ} \mathrm{C} ;{ }^{1} \mathrm{H} \mathrm{NMR}\left(\mathrm{CDCl}_{3}\right) \delta 0.92(\mathrm{t}, J=5 \mathrm{~Hz}, 6 \mathrm{H})$, $1.36-1.43(\mathrm{~m}, 12 \mathrm{H}), 2.54(\mathrm{t}, J=5 \mathrm{~Hz}, 4 \mathrm{H}), 6.82-6.88(\mathrm{~m}, 8 \mathrm{H}), 6.96(\mathrm{~s}, 4 \mathrm{H}), 7.41-7.45(\mathrm{~m}, 8 \mathrm{H}) ;{ }^{13} \mathrm{C} \mathrm{NMR}\left(\mathrm{CDCl}_{3}\right) \delta 14.4$, 22.8, 28.3, 32.1, 34.4, 127.0, 127.1, 128.9, 129.06, 129.09, 129.2, 129.5, 139.0, 139.1, 139.7, 141.8, 141.9, 142.3.

Following a similar procedure as above, SB1, SB3, and SB4 were prepared and their spectral data are summarized below: 
SB1: yield $0.27 \mathrm{~g}$, 91\% (after chromatography with hexanes-ethyl acetate as eluent); ${ }^{1} \mathrm{H} \mathrm{NMR}\left(\mathrm{CDCl}_{3}\right) \delta 2.15$ (s, 6H), 6.81-6.87 (m, 8H), $6.92(\mathrm{~s}, 4 \mathrm{H}), 7.37-7.39(\mathrm{~m}, 8 \mathrm{H}) ;{ }^{13} \mathrm{C} \mathrm{NMR}\left(\mathrm{CDCl}_{3}\right)$ \& 21.2, 127.1, 128.4, 129.1 129.2, 129.3, 129.5, $134.0,139.2,139.8,142.0,142.2,143.2$. SB3: yield $0.93 \mathrm{~g}$, 98\% (after crystallization from a mixture of dichloromethane/acetonitrile); mp 308-309 ${ }^{\circ} \mathrm{C} ;{ }^{1} \mathrm{H}$ NMR $\left(\mathrm{CDCl}_{3}\right) \delta 6.89(\mathrm{~s}, 8 \mathrm{H}), 7.02(\mathrm{~s}, 4 \mathrm{H}), 7.11(\mathrm{~s}, 10 \mathrm{H}), 7.38-7.41$ $(\mathrm{m}, 8 \mathrm{H}) ;{ }^{13} \mathrm{C} \mathrm{NMR}\left(\mathrm{CDCl}_{3}\right) \delta$ 126.8, 127.1, 127.2, 127.9, 129.1, 129.3, 129.4, 129.5, 130.4, 131.3, 139.6, 140.0, 141.7, $142.03,142.09,142.5,142.8$. SB4: yield $0.89 \mathrm{~g}$, 96\% (after crystallization from a mixture of dichloromethane/acetonitrile); $\mathrm{mp} 303-304{ }^{\circ} \mathrm{C} ;{ }^{1} \mathrm{H} \mathrm{NMR}\left(\mathrm{CDCl}_{3}\right) \delta 3.76(\mathrm{~s}, 6 \mathrm{H}), 6.68(\mathrm{~d}, \mathrm{~J}=8 \mathrm{~Hz}, 4 \mathrm{H}), 6.87(\mathrm{~s}, 8 \mathrm{H}), 7.02$ (d, $J=7 \mathrm{~Hz}, 8 \mathrm{H}), 7.37-7.40(\mathrm{~m}, 8 \mathrm{H}) ;{ }^{13} \mathrm{C} \mathrm{NMR}\left(\mathrm{CDCl}_{3}\right) \delta 55.3,113.3,127.0,127.2,129.1,129.3,129.5,130.5,132.5$, $135.6,139.4,140.0,140.2,142.0,142.1,143.0,158.3$.

\section{Acknowledgment}

We thank the National Science Foundation (Career Award) for financial support.

\section{Supporting Information}

General experimental methods, ${ }^{1} \mathrm{H} /{ }^{13} \mathrm{C}$ NMR spectra, the ORTEP diagrams, and the X-ray crystallographic data for various compounds. This material is available free of charge via the Internet at http://pubs.acs.org.

- PDF

$0 \quad$ j0802579f si 001.pdf (1.59 MB)

- Crystallographic Information File

o $\underline{0} 0802579 f$ si 002.cif (27.58 kB)

$0 \quad$ j0802579f si 003.cif (9.69 kB)

0 j0802579f_si 004.cif (20.48 kB)

$0 \quad$ jo802579f si 005.cif (20.38 kB)

0 jo802579f si 006.cif (22.46 kB)

o j0802579f_si 007.cif (14.44 kB)

o $\underline{\text { jo802579f si 008.cif (48.11 kB) }}$

o j0802579f_si 009.cif (12.75 kB)

A Versatile Synthesis of Electroactive Stilbenoprismands for Effective Binding of Metal Cations Showing 1/9: j0802579f_si_001.pdf

\section{References}

1 (a) Heirtzler, F. R.; Hopf, H.; Jones, P. G.; Bubenitachek, P.; Lehne, V. J. Org. Chem. 1993, 58, 2781 (b) Gano, J. E.; Subramaniam, G.; Birnbaum, R. J. Org. Chem. 1990, 55,4760 (c) Yang, R.-H.; Chan, W.-H.; Lee, A. W. 
M.; Xia, P.-F.;Zhang, H.-K.; Li, K. J. Am. Chem. Soc. 2003, 125, 2884 (d)Chebny, V. J.; Rathore, R. J. Am. Chem. Soc. 2007, 128, 8458 (e) Prodi, L.;Bolletta, F.; Montalti, M.; Zaccheroni, N. Coord. Chem. Rev. 2000, 205, 59

(f)Ikeda, M.; Tanida, T.; Takeuchi, M.; Shinkai, S. Org. Lett. 2000, 2, 1803 (g) Lindeman, S.

V.; Rathore, R.; Kochi, J. K Inorg. Chem. 2000, 39, 5707 and references cited therein

2(a) Munakata, M.; Wu, L. P.; Kuroda-Sowa, T.; Maekawa, M.; Suenaga, Y.; Sugimoto, K. Inorg. Chem. 1997,36, 4903

(b) Munakata, M.; Wu, L. P.; Ning, G. L.; Kuroda-Sowa, T.;Maekawa, M.; Suenaga, Y.; Macao, Y. J. Am. Chem.

Soc. 1999, 121, 4968

(c) Szigeti, Z.; Malon, A.; Vigassy, T.; Csokai, V.; Grün, A.; Wygladacz, K.; Ye, N.; Xu, C.;Bitter, V.

J.; Rathore, I.; Bakker, R.; Pretsch, E. Anal. Chim. Acta 2006, 572, 1 (d) Chebny, V.

J.; Banerjee, M.; Rathore, R. Chem. Eur. J. 2007, 13, 6508 and references therein

3.(a) Pierre, J. L.; Baret, P.; Chautemps, P.; Armand, M. J. Am. Chem. Soc. 1981, 103, 2986

(b) Pierre, G.; Baret, P.; Chautemps, P.; Pierre, J. L. Electrochim. Acta 1983, 28,1269

4 (a) Kang, H. C.; Hanson, A. W.; Eaton, B.; Boelelheide, V. J. Am. Chem. Soc. 1985, 107, 1979

(b) Schmidbaur, H.; Hager, R.; Huber, B.; Muller, G. Angew. Chem., Int. Ed. 1987,26, 338

(c) Probst, T.; Steigelmann, O.; Riede, J.; Schmidbaur, H. Angew. Chem., Int. Ed. 1990, 29, 1397

${ }^{5}$ See: Heirtzler, F. R.; Hopf, H.; Jones, P. G.; Bubenitschek, P. Tetrahedron Lett. 1995, 36,1239

${ }_{6}^{6}$ Compare: Emond, S. J.; Debroy, P.; Rathore, R. Org. Lett. 2008, 10, 389

7(a) Baumstark, A. L.; McCloskey, C. J.; Witt, K. E. J. Org. Chem. 1978, 43, 3609 (b) Shukla, R.; Lindeman, S. V.; Rathore, R. J. Org. Chem. 2006, 71, 6124 and references cited therein

8 (a) Fujioka, Y. Bull. Chem. Soc. Jpn. 1985, 58, 481 (b) Ozasa, S.; Hatada, N.;Fujioka, Y.; Ibuki, E. Bull. Chem. Soc. Jpn. 1980, 53, 2610

9(a) Suzuki, A. Chem. Commun. 2005, 4759 (b) Hassan, J.;Sevignon, M.; Gozzi, C.; Schulz, E.; Lemaire, M. Chem. Rev. 2002, 102, 1359 and references cited therein

${ }^{10}$ Tunney, S. E.; Stille, J. K. J. Org. Chem. 1987, 52, 748

${ }^{11}$ With the exception of the slight broadening in the first spectrum in Figure 1 (with 0.2 equiv of $\mathrm{Ag}^{+}$, which may arise due to the low concentration of $\left[\mathbf{S B 2}, \mathrm{Ag}^{+}\right]$), the other spectra in Figure 1 did not show any significant line broadening to allow the extraction of a reliable $K_{\mathrm{d}}$ value. Compare: Rathore, R.; Chebny, V. J.; Abdelwahed, S. H. J. Am. Chem. Soc. 2004, 127, 8012. Also see: Connors, K. A. Binding Constants; Wiley: New York, 1987.

12(a) Note that an exposure of a solution of SB4 (or SB3) to solid $\mathrm{CF}_{3} \mathrm{SO}_{3} \mathrm{Ag}$ in anhydrous dichloromethane (in the absence of methanol) produced a colored solution of the SB4 cation radical as judged by spectrophotometric analysis. (b) Owing to the poor solubility of SB1, it was not utilized in the subsequent studies.

${ }^{13}$ Rathore, R.; Lindeman, S. V.; Kumar, A. S.; Kochi, J. K. J. Am. Chem. Soc. 1998, 120, 6931

${ }^{14}$ Rathore, R.; Burns, C. L.; Deselnicu, M. I. Org. Synth. 2005, 82, 1. Also see: Rathore, R.; Kochi, J. K. J. Org. Chem. 1995, 60, 4399

${ }_{15}$ Note that the repeated attempts to obtain single crystals of monocationic $\mathbf{S B 4}{ }^{+} \cdot \mathrm{SbCl}_{6}^{-}$, even in the presence of excess neutral SB4, were thus far unsuccessful. However, a reviewer suggested that it may be feasible to obtain single crystals of monocationic SB4+ using a larger counter anion, e.g., see: Nelsen, S.

F.; Ismagilov, R. F.; Powell, D. R. J. Am. Chem. Soc. 1997, 119, 10213

16The ideal values for the sum of the intracyclic bond angles for the planar rings are the following: $3 \times 60=180^{\circ}$ for 3 -membered cycles, $4 \times 90=360^{\circ}$ for 4 -membered cycles, $5 \times 108=540^{\circ}$ for 5 -membered cycles, $6 \times$ $120=720^{\circ}$ for 6 -membered cycles, etc. A deviation from the ideal value of the sum of the intracyclic bond angles results either in the nonplanar conformations (e.g., the chair conformation of cyclohexane) or distortion of the bonds (e.g., the "banana" bonds in cyclopropane).

17 (a) Shultz, D. A.; Fox, M. A. J. Am. Chem. Soc. 1989, 111, 6311 (b)Ma, J.; Zimmt, M. B. J. Am. Chem. Soc. 1992, 114, 9723

${ }^{18}$ Berlman, I. B. Handbook of Fluorescence Spectra of Aromatic Compounds, 2nd ed.; Academic Press: New York, 1971. 
${ }^{19}$ Compare: (a) Banerjee, M.; Emond, S. J.; Lindeman, S. V.; Rathore, R J. Org. Chem. 2007, 72,8054 (b) Gano, J. E.; Osborn, D. J., III; Kodali, N.; Sekher, P.; Liu, M.;Luzik, E. D, Jr J. Org. Chem. 2003, 68, 3710

${ }^{20}$ Banerjee, M.; Lindeman, S. V.; Rathore, R. J. Am. Chem. Soc. 2007, 129, 8070

21For example: Momicchioli, F.; Bruni, M. C.; Baraldi, I. J. Phys. Chem. 1972, 26, 3983

22Rathore, R.; Burns, C. L. J. Org. Chem. 2003, 68, 4071- 4074

$\underline{23}$ Fujioka, Y. Bull. Chem. Soc. Jpn. 1984, 57, 3494 